\title{
Using Nemerow's Pollution Index Method for Water Quality Assessment of Cimanuk River in West Java
}

\author{
Ihya Sulthonuddin ${ }^{1}$, Djoko Mulyo Hartono ${ }^{2}$, Chairil Abdini Abidin Said ${ }^{1}$ \\ \{ihya.sulthonuddin@ui.ac.id ${ }^{1}$, djokomh@eng.ui.ac.id ${ }^{2}$, cabdini@gmail.com ${ }^{1}$ \} \\ ${ }^{1}$ Environmental Science Study Program, School of Environmental Science, Universitas Indonesia, \\ Jakarta, Jakarta, Indonesia, 10340 \\ ${ }^{2}$ Environmental Engineering Study Program, Faculty of Engineering, Universitas Indonesia, \\ Depok, West Java, Indonesia, 16424
}

\begin{abstract}
The river water is one of the water resources that important in managing environmental sustainability, increasing economic growth, and realizing the social welfare of communities. This study aims to assess and analyze water quality of the Cimanuk river. The analyze of water quality in the Cimanuk river based on the Regulation of Governor of West Java (GWJ) Class 1, United Kingdom Technical Advisory Group (UKTAG), United States Environmental Protection Agency (USEPA), Ministry of Environmental Government Japan (MOEG), and Departement of Environmental Malaysia (DOE). Nemerow's pollution index (NPI) method used to assess the water in the Cimanuk river from the years 2013 to 2018. River water sampling stations of the Cimanuk river are Boyongbong, Sukaregang, Tomo, and Jatibarang. Base on seven physicochemical parameters, this research found that the Cimanuk river is not meet the water quality standards with the value of TSS $(81.57 \pm 132.69 \mathrm{mg} / \mathrm{L})$, BOD $(8.41 \pm 6.53 \mathrm{mg} / \mathrm{L}), \mathrm{COD}$ $(33.92 \pm 26.51 \mathrm{mg} / \mathrm{L})$, DO $(5.54 \pm 1.67 \mathrm{mg} / \mathrm{L})$, and Ammonia $(0.21 \pm 0.31 \mathrm{mg} / \mathrm{L})$. The degradation of river water quality in the Cimanuk river indicated by increasing NPI value. NPI value of the Cimanuk river ranging from 1.04 to 7.51. The water quality status of the Cimanuk river has been changing from slightly to moderately polluted. Nowadays, water from the Cimanuk river not suitable to be used as a drinking water source. However, it is still feasible to irrigate agricultural land and plantations.
\end{abstract}

Keywords: Cimanuk river, Nemerow's pollution index, Water quality assessment.

\section{Introduction}

The river water is one of the water resources that important in managing environmental sustainability, increasing economic growth, and realizing the social welfare of communities. That is the function as a source of raw water for drinking water, clean water, environmental conservation, agricultural, fisheries, livestock, and others. Based on Environment Statistics of Indonesia in 2018, the rivers water quality in Indonesia are $46 \%$ highly polluted, $32 \%$ moderately to highly polluted, $14 \%$ moderately polluted, $8 \%$ slightly to moderately polluted, and no one river meet the water quality standards [1]. And four of the seven rivers in West Java liked the Citarum river [2], the Ciliwung river [3], the Cisadane river, and the Citanduy river highly polluted [1]. Some studies also show the Cilamaya river [2], the Cileungsi river [4], and the Cimanuk river [5] highly polluted. And actually, the seven rivers in West Java used as raw water for drinking water in the Regional Drinking Water Company (PDAM). 
The river water pollution that occurs a lot in rivers is one of the environmental problems and important issues need to get serious action from the government (central and regional) and various parties, academics, researchers, the local communities, the private sector, and other stakeholders [5]. If linked to the Sustainable Development Goals (SDGs), the issue of river water pollution in West Java is important because it is closely related to the goal number 6 of SGDs, that in 2030 can ensure the availability, managing sustainable clean water and sanitation, improve the river water quality, and reduce the river water pollution. The river water pollution in the Cimanuk river are the weakness to the availability of clean water and the threat to the sustainability of water resources in West Java. So, to address these issues, this research aims to assess and analyze water quality of the Cimanuk river in West Java.

\section{Methods}

\subsection{Water sampling stations}

The water sampling stations of the Cimanuk river are at Boyongbong, Sukaregang, Tomo, and Jatibarang in West Java (Table 1).

Table 1. Water sampling stations of the Cimanuk river

\begin{tabular}{lllll}
\hline \multirow{2}{*}{ Segments } & \multirow{2}{*}{ Sampling stations } & \multicolumn{2}{c}{ Koordinates } & \multirow{2}{*}{ Districts } \\
\cline { 3 - 4 } & & East & South & \\
\hline Upstream & Boyongbong & $107^{\circ} 49^{\prime} 33.6^{\prime \prime} \mathrm{E}$ & $07^{\circ} 15^{\prime} 56.1^{\prime \prime} \mathrm{S}$ & Garut \\
Upstream & Sukaregang & $107^{\circ} 54^{\prime} 33.3^{\prime \prime} \mathrm{E}$ & $07^{\circ} 11^{\prime} 39.4^{\prime \prime} \mathrm{S}$ & Sumedang \\
Midstream & Tomo & $108^{\circ} 08^{\prime} 03.1^{\prime \prime} \mathrm{E}$ & $06^{\circ} 45^{\prime} 43.1^{\prime \prime} \mathrm{S}$ & Majalengka \\
Downstream & Jatibarang & $108^{\circ} 17^{\prime} 45.6^{\prime \prime} \mathrm{E}$ & $06^{\circ} 28^{\prime} 07.0^{\prime \prime} \mathrm{S}$ & Indramayu \\
\hline
\end{tabular}

\subsection{Water quality analysis}

The water quality analysis of the Cimanuk river based on the seven physicochemical parameters, Temperature, Total Suspended Solid (TSS), pH, Biochemical Oxygen Demand (BOD), Chemical Oxygen Demand (COD), Dissolves Oxygen (DO), and Ammonia. The water quality of the Cimanuk river from years 2013 to 2018 obtained by comparing the test results with the water quality standards of Regulation of the Governor of West Java (GWJ) Class 1 [5][6]; United Kingdom Technical Advisory Group, Water Framework Directive (UKTAG) [7]; United States Environmental Protection Agency, Water Quality Standards for Surface Waters (USEPA) [8][9]; Ministry of Environmental Government Japan, Environmental Quality Standard for Water (MOEG) [10]; and Departement of Environmental Malaysia, National Water Quality Standards for Malaysia (DOE) [11] (Table 2).

Table 2. Water quality standards for river

\begin{tabular}{lcccccc}
\hline \multicolumn{1}{c}{ Parameters } & Unit & GWJ & UKTAG & USEPA & MOEG & DOE \\
\hline Physical & & & & & & \\
Temperature & ${ }^{\circ} \mathrm{C}$ & $25 \pm 3$ & $25 \pm 3$ & $25 \pm 3$ & $25 \pm 3$ & $25 \pm 3$ \\
Total Suspended Solid (TSS) & $\mathrm{mg} / \mathrm{L}$ & 50 & 50 & 50 & 50 & 25 \\
Chemical & & & & & & \\
pH & - & $6.0-9.0$ & $6.5-8.5$ & $5.5-8.5$ & $6.5-8.5$ & $6.5-8.5$ \\
Chemical Oxygen Demand (COD) & $\mathrm{mg} / \mathrm{L}$ & 10 & 4 & 25 & 10 & 10 \\
Biochemical Oxygen Demand (BOD) & $\mathrm{mg} / \mathrm{L}$ & 2 & 3 & 5 & 1 & 1 \\
Dissolves Oxygen (DO) & $\mathrm{mg} / \mathrm{L}$ & 6 & 7 & 8.5 & 7.5 & 7 \\
Ammonia & $\mathrm{mg} / \mathrm{L}$ & 0.1 & 0.2 & 0.2 & 0.2 & 0.5 \\
\hline
\end{tabular}




\subsection{Nemerow's pollution index}

The water quality status of the Cimanuk river assessed by Nemerow's pollution index method based on the Decree of the Minister of Environment of Republic Indonesia Number 115/2003 concerning the Water Quality Status [12][13][14][15] and the United States Environmental Protection Agency (USEPA) [16][17][18]. Nemerow's pollution index calculated by the following formula.

$$
\mathrm{NPI}_{\mathrm{j}}=\sqrt{\frac{\left(\mathrm{C}_{\mathrm{i}} / \mathrm{L}_{\mathrm{ij}}\right)_{\mathrm{M}}^{2}+\left(\mathrm{C}_{\mathrm{i}} / \mathrm{L}_{\mathrm{ij}}\right)_{\mathrm{R}}^{2}}{2}}
$$

Where: $\mathrm{NPI}_{\mathrm{j}}$ is Nemerow's pollution index for a specified river water quality purpose $(\mathrm{j})$, $\mathrm{L}_{\mathrm{ij}}$ is standard water quality parameter for each parameter at specified river water quality purpose $(\mathrm{j}), \mathrm{C}_{\mathrm{i}}$ is measured river water quality parameters, $\left(\mathrm{C}_{\mathrm{i}} / \mathrm{L}_{\mathrm{ij}}\right)_{\mathrm{M}}$ is $\mathrm{C}_{\mathrm{i}} / \mathrm{L}_{\mathrm{ij}}$ maximum, and $\left(\mathrm{C}_{\mathrm{i}} / \mathrm{L}_{\mathrm{ij}}\right)_{\mathrm{R}}$ is $\mathrm{C}_{\mathrm{i}} / \mathrm{L}_{\mathrm{ij}}$ average. $\mathrm{NPI}_{\mathrm{j}}$ was then compared with the criteria of water quality status shown in Table 3.

Table 3. Nemerow's pollution index and criteria of water quality status

\begin{tabular}{ll}
\hline Nemerow's pollution index & Water quality status \\
\hline $0.0 \leq \mathrm{NPI}_{\mathrm{j}} \leq 1.0$ & Meet water quality standards \\
\hline $1.0 \leq \mathrm{NPI}_{\mathrm{j}} \leq 5.0$ & Slightly polluted \\
\hline $5.0 \leq \mathrm{NPI}_{\mathrm{j}} \leq 10.0$ & Moderately polluted \\
\hline $\mathrm{NPI}_{\mathrm{j}} \geq 10.0$ & Highly polluted \\
\hline
\end{tabular}

\section{Results and Discussion}

The Cimanuk river is the second-longest river in West Java with the river flow length 180 $\mathrm{Km}$. The Cimanuk river rainfall average between 1,500 to 3,000 millimeters per year and 347,697 ha watershed area (Figure 1). The Cimanuk watershed divided into three segments or sub-watershed. (1) The Cimanuk upstream has an area 145,677 ha in Sumedang and Garut District. (2) The Cimanuk midstream has an area of 114,477 ha in Majalengka and Sumedang District. And (3) The Cimanuk down stream has an area of 81,299 ha in Indramayu District. The Cimanuk river is a water supply center river to Waduk Jatigede for irrigate agricultural land and PLTA in West Java. The Cimanuk river functions as a water resource used for raw water sources in 4 Regional Water Supply Companies (PDAM) such as "Tirta Intan Garut", "Tirta Medal Sumedang“, "Tirta Darma Majalengka“, and "Tirta Darma Ayu Indramayu" to support community activities. However, community activities (such as domestic, agricultural, livestock, and industrial waste disposal activities) that are uncontrolled at the Cimanuk river (from upstream to downstream) indicated to decreased the river water quality and increased the river water pollution [19]. Therefore, the river water quality in the Cimanuk river must be monitored by its river water quality, maintained by the availability of its water resources, controlled for its pollution level, and managed for its environmental sustainability.

Efforts to control the water pollution of the Cimanuk river by the regional government and related agencies have not been implemented properly. All of that, if not carried out the management of river water quality and control of river water pollution will result in highly polluted rivers and reduced availability of clean water and threaten the sustainability of the Cimanuk river. The Cimanuk river is not one of the government priority rivers for rehabilitation yet, but it would be the regional government priority in West Java to conserve it. 


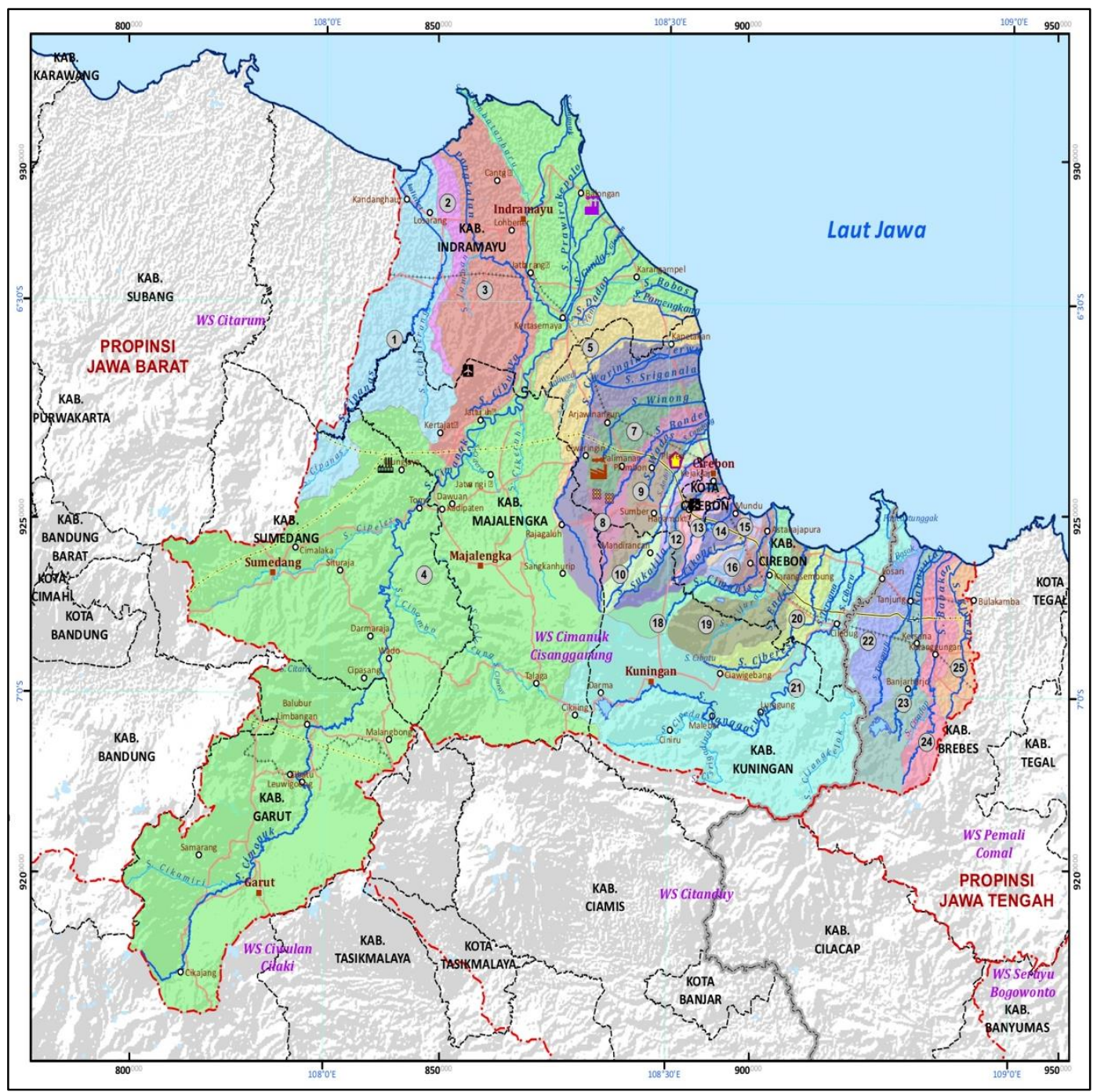

Fig. 1. Map of the Cimanuk Watersheed in West Java

Based on data reported by the Environment Agency of West Java Province, most of the river water pollution in the Cimanuk river originates from domestic and small and mediumsized industrial waste disposal activities (Figure 2). Water quality management and control of Cimanuk River water pollution have been carried out by several government agencies or institutions such as Environmental Agency of West Java Province (DLH); The CimanukCisanggarung River Basin (BBWS Cimanuk-Cisanggarung); and Regional Task Implementing Unit of Cimanuk-Cisanggarung River Basin Management Agency (BPSDA CimanukCisanggarung). 


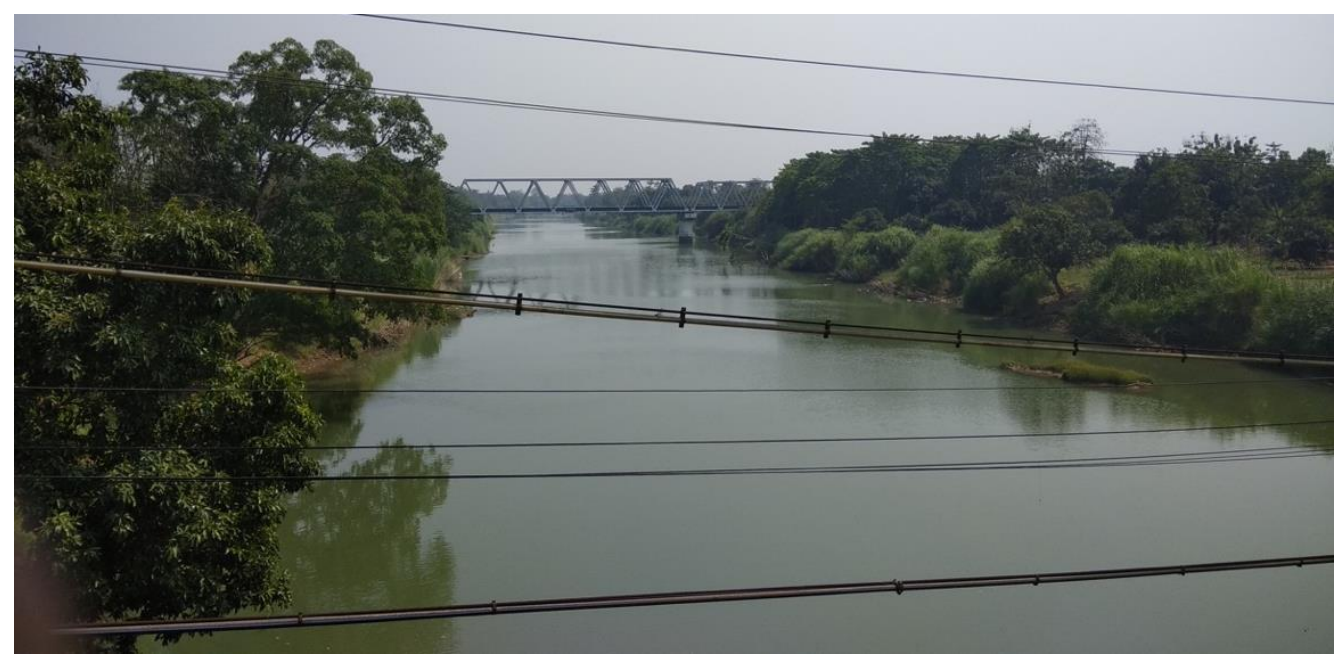

Fig. 2. The Cimanuk river conditions in West Java

Over the last six years (from 2013 to 2018), the test result of river water quality in the Cimanuk river has been declining dramatically. The river water quality of the Cimanuk river shown in Figure 3. Based on Figure 3, temperature and $\mathrm{pH}$ are the only parameters that meet the water quality standards (Figure 3.a and Figure 3.c) where the value of Temperature (from 19 to $32,70^{\circ} \mathrm{C}$ ) and $\mathrm{pH}$ (from 5.80 to 11 ). On the other hand, parameters TSS, BOD, COD, DO, and Ammonia does not meet the water quality standards with the following values of TSS (from 2 to $892 \mathrm{mg} / \mathrm{L}$ ), BOD (from 2 to $38 \mathrm{mg} / \mathrm{L}$ ), COD (from 4 to $156 \mathrm{mg} / \mathrm{L}$ ), DO (from 08 to $8 \mathrm{mg} / \mathrm{L}$ ), and Ammonia (from 0.01 to $2 \mathrm{mg} / \mathrm{L}$ ). Based on Figure 3.h, Nemerow's pollution index of the Cimanuk river decreased annually from 2013 to 2018, but increased annually from Boyongbong (as upstream) to Jatibarang (as downstream).

The average NPI value of the Cimanuk river is $2,78 \pm 1,44$ indicating moderately polluted (Figure 3.h). The highest NPI value the occurred in 2014 at Jatibarang based on the MOEG is 7.51 indicating the Cimanuk river downstream moderately polluted. The lowest NPI value the occurred in 2018 at Tomo based on the USEPA is 0.81 indicating the Cimanuk river midstream still meet the water quality standards. And the NPI value of the Cimanuk river base on GWJ (from 1.13 to 5.52), USEPA (from 1.09 to 3.51), UKTAG (from 1.04 to 6.51), MOEG (from 1.16 to 7.51 ), and DOE (from 1.13 to 7.39 ). Specifically, the NPI value base on the sampling station at Boyongbong (from 1.34 to 2.94), Sukaregang (from 1.74 to 5.52), Tomo (from 1.04 to 4.49), and Jatibarang (from 1.19 to 7.51 ).

The highest NPI value of the Cimanuk river is 7.51 in Jatibarang which means highly polluted. The high NPI value in Jatibarang because there are many uncontrollable waste disposal from domestic waste, fish crackers industries, batik industries, regional public hospital, agricultural, livestock, traditional and modern market waste along the Cimanuk River downstream. And many fish cracker industries and batik industries in the Cimanuk river downstream (Jatibarang, Indramayu District) I not yet wastewater treatment plant (WWTP). 


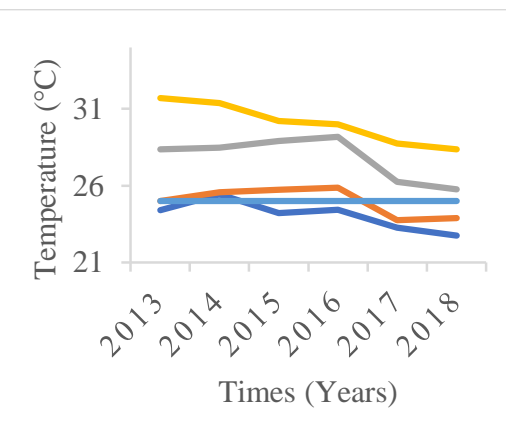

(a)

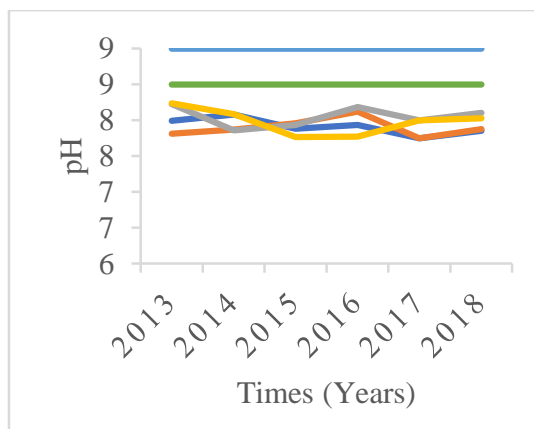

(c)

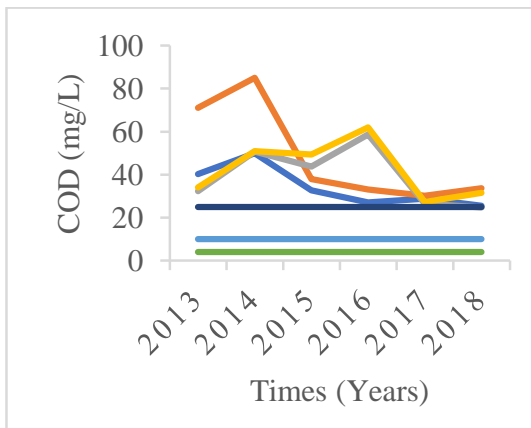

(e)

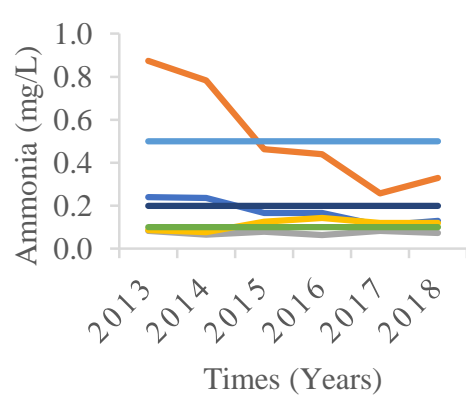

(g)

Fig. 3. River water quality of the Cimanuk river (a) Temperature, (b) TSS, (c) pH, (d) BOD, (e) COD, (f) DO, (g) Ammonia, and (h) Nemerow's pollution index

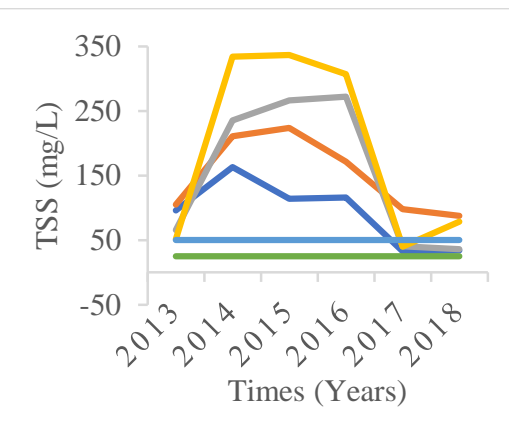

(b)

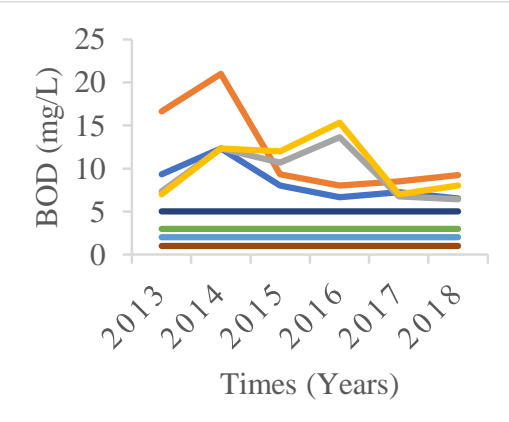

(d)

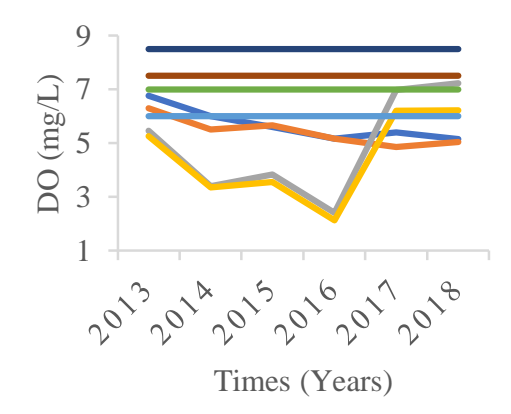

(f)

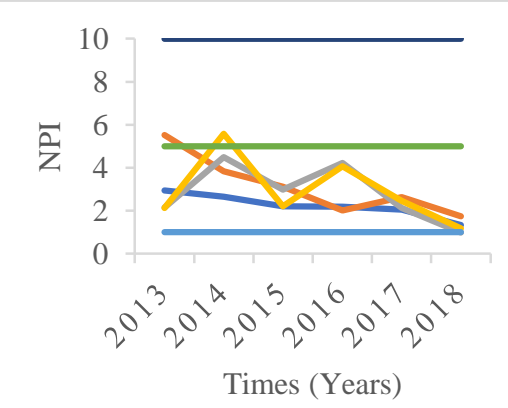

(h) 


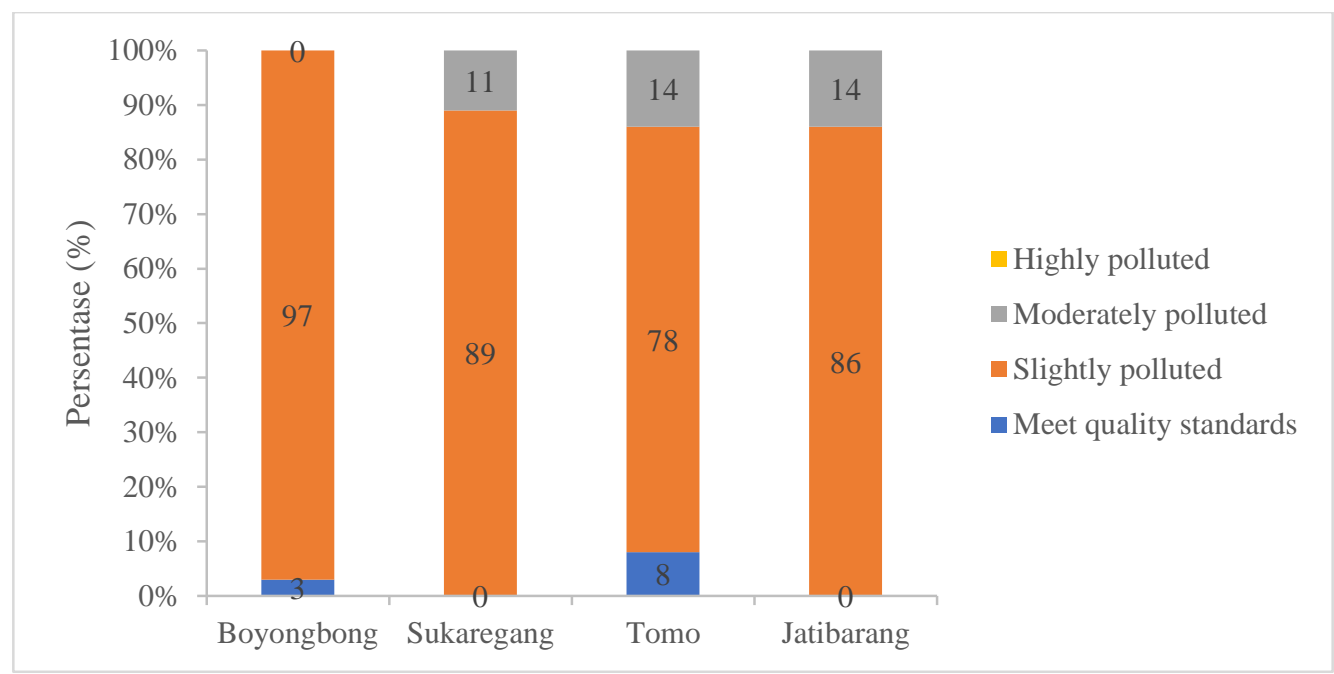

Fig. 4. Nemerow's pollution index value of the Cimanuk river

Based on the results, TSS, BOD, COD, and Ammonia parameters are parameters that often increased the NPI value in the Cimanuk river. The highest NPI value based on TSS parameters (26.69) occurred in 2014 in Jatibarang which indicated the Cimanuk river downstream highly polluted. The highest NPI value based on BOD parameters (29.34), COD (29.98), and Ammonia (10.61) occurred in 2013 in Sukaregang which indicates that the Cimanuk river upstream highly polluted. The parameters that most influence the NPI value in the Cimanuk river downstream (Jatibarang) are TTS, BOD, COD, and Ammonia parameters. Based on the test results, the highest NPI value based on TSS parameters (26.69), BOD (18.39), and COD (18.89) occurred in 2014, indicating the Cimanuk river downstream was highly polluted. In 2018, there are no significant parameters that increase the NPI value to be highly polluted. Most of the NPI values in 2018 indicated the Cimanuk river slightly polluted (Figure 4).

Figure 4. shows that $88 \%$ of the water quality status of the Cimanuk river (from upstream to downstream) slightly polluted. The condition of the Cimanuk river (from upstream to downstream) poor. The water quality status of the Cimanuk river (from upstream to downstream) slightly to moderate polluted. Base on these results, the water from the Cimanuk river not suitable to be used as a drinking water source. However, it is still feasible to irrigate agricultural land and plantations. The water from the Cimanuk river can feasible to use as a source of raw water but more the water treatment and the high cost needed to produce clean water in the the Regional Drinking Water Company (PDAM). River water quality assessment of the Cimanuk river carried out as an effort to manage and control the water quality of the Cimanuk river so that the river can be harnessed and can be used to their usefulness. In this study, an increase in collaboration between regional government (Environmental Agency (DLH), Spatial and Urban Planning Agency (DTRW)), local communities, and private sectors needed to conserve and preserve the Cimanuk river.

The recommended of water pollution control strategy for the Cimanuk river management is a progressive growth strategy, which is to implement policies by (a) improving the water 
pollution control infrastructure of the Cimanuk river (from Boyongbong to Jatibarang) through the establishment of integrated waste management and communal (WWTP), (b) increasing roles and participation academics, researchers, and community groups in every activity of planning and implementing water pollution control in the Cimanuk river, and (c) increasing the coordination of government agencies/institutions with various parties in determining water pollution control policies in the Cimanuk river.

\section{Conclutions}

The water from the Cimanuk river not meet the water quality standards of Regulation of the Governor of West Java (GWJ) Class 1; United Kingdom Technical Advisory Group, Water Framework Directive (UKTAG); United States Environmental Protection Agency, Water Quality Standards for Surface Waters (USEPA); Ministry of Environmental Government Japan, Environmental Quality Standard for Water (MOEG); and Departement of Environmental Malaysia, National Water Quality Standards for Malaysia (DOE). Nemerow‘s pollution index (NPI) of the Cimanuk river ranging from 1.04 to 7.51 (slightly polluted to moderately polluted). The water quality status of the Cimanuk river changing from slightly polluted to moderately polluted. Nowadays, the water from the Cimanuk river not suitable to be used as a drinking water source. However, it is still feasible to irrigate agricultural land, fisheries, and plantations.

\section{Reference}

[1] Purba, W.S., Safitri, P.A., Andianti, R.: Environment Statistics of Indonesia 2018. BPS - Statistics Indonesia (2018)

[2] Sutadian A.D., Muttil, N., Yilmaz, A.G., Perera, B.J.C.: Development of a water quality index for rivers in West Java Province Indonesia. Ecological Indicators. Vol. 85, pp. 966-982 (2018)

[3] Yanidar, R., Hartono, D.M., Moersidik, S.S.: Water quality assessment for self-sufficient water resources for DKI Jakarta. IOP Conference Series: Earth and Environmental Science. Vol. 106, 012056 (2017)

[4] Sidabutar, N.V., Namara, I., Hartono, D.M., Soesilo T.E.B.: The effect of anthropogenic activities to the decrease of water quality. IOP Conference Series: Earth and Environmental Science. Vol. 67, 012034 (2017)

[5] Sulthonuddin, I., Hartono, D.M., Utomo, S.W., Said, C.A.A.: Water quality qssessment of Cimanuk river in West Java using STORET method. IOP Conference Series: Earth and Environmental Science. Vol. 239, 012007 (2019)

[6] Sulthonuddin, I., Hartono, D.M., Utomo, S.W.: Water quality assessment of Cimanuk river in West Java using pollution index. E3S Web of Conferences. Vol. 68, 04009 (2018)

[7] United Kingdom Technical Advisory Group About Water Framework Directive (UKTAG).

[8] United States Environmental Protection Agency About Water Quality Standards for Surface Waters (USEPA).

[9] de Jong, E.B.P., Ragas, A.M.J., Nooteboom, G., Mursidi, M.: Changing water quality in the middle Mahakam Lakes: water quality trends in a context of rapid deforestation, mining and palm oil plantation development in Indonesia's middle Mahakam Wetlands. Wetlands. Vol. 35, pp. 733-744 (2015)

[10] Ministry of Environmental Government Japan About Environmental Quality Standard for Water (MOEG).

[11] Departemen of Environmental Malaysia About National Water Quality Standards for Malaysia (DOE). 
[12] Effendi, H., Romanto, Wardiatno, Y.: Water quality status of Ciambulawung river, Banten Province, based on pollution index and NSF-WQI. Procedia Environmental Sciences. Vol. 24, pp. 228237 (2015)

[13] Effendi, H.: River water quality preliminary rapid assessment using pollution index Procedia. Environmental Sciences.Vol. 33, pp. 562-567 (2016)

[14] Puspita, I., Ibrahim, L.D., Hartono, D.M.: The influence of the behavior of the people living in the riverbanks area to decrease the water quality of the Karang Anyar River in Tarakan City. Human and Environmental Journal. Vol. 23, No. 2, pp. 249-258 (2016)

[15] Pohan, D.A.S., Budiyono, Syafrudin: Analysis of river water quality to determine designation in terms of environmental aspects. Journal of Environmental Sciences. Vol. 14, No. 2, pp. 63-17 (2016)

[16] Dawood, A.S.: Using of Nemerow's Pollution Index (NPI) for water quality assessment of some Basrah Marshes, South of Iraq. Journal of Babylon University. Vol. 25, No. 5, pp. 1708-1720 (2017) [17] Zhang, Q., Feng, M., Hao, X.: Application of nemerow index method and integrated water quality index method in water quality assessment of Zhangze reservoir. IOP Conference Series: Earth and Environmental Science. Vol. 128, 012160 (2018)

[18] Donald, A.E., Blessing, U.A.: Index approach to water quality assessment of a south eastern Nigerian river. International Journal of Fisheries and Aquatic Studies. Vol. 7, No. 1, pp. 153-159 (2019) [19] Sulthonuddin, I., Hartono, D.M., Said, C.A.A., Utomo, S.W.: River water pollution indication in the Cimanuk river downstream, Indramayu District. IOP Conference Series: Earth and Environmental Science. Vol. 239, 012010 (2019) 